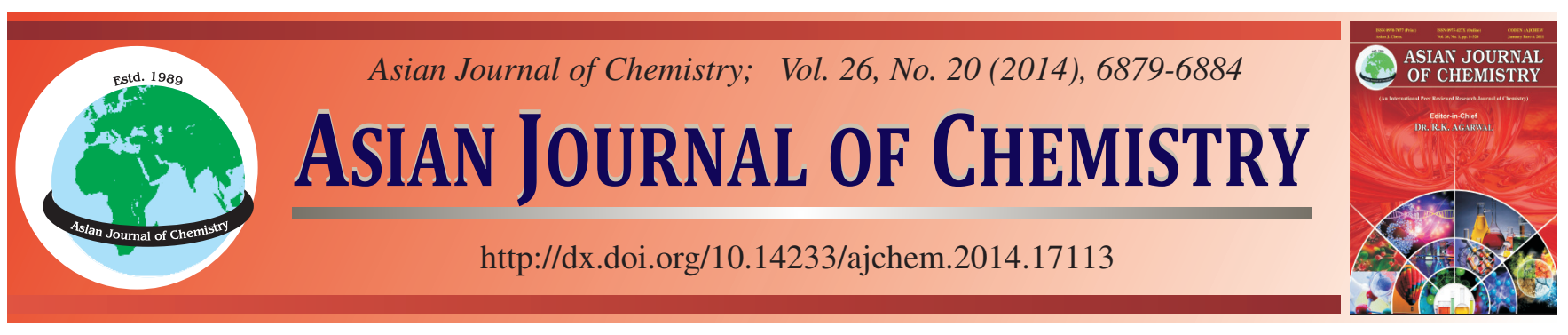

\title{
Synthesis of $\mathrm{CaLa}_{2}\left(\mathrm{MoO}_{4}\right)_{4}: \mathrm{Er}^{3+} / \mathrm{Yb}^{3+}$ Particles by Microwave-Assisted Sol-Gel Method and Their Upconversion Photoluminescence Properties
}

\author{
Chang Sung Lim
}

Department of Advanced Materials Science \& Engineering, Hanseo University, Seosan 356-706, Republic of Korea

Corresponding author: Tel/Fax: +82 416601445; E-mail: cslim@ @anseo.ac.kr

Received: 24 January 2014

Accepted: 23 April 2014;

Published online: 25 September 2014;

AJC-16030

$\mathrm{CaLa}_{2}\left(\mathrm{MoO}_{4}\right)_{4}: \mathrm{Er}^{3+} / \mathrm{Yb}^{3+}$ upconversion particles of were successfully synthesized by a microwave-assisted sol-gel method, followed by heat-treatment. Well-crystallized particles formed after heat-treatment at $900{ }^{\circ} \mathrm{C}$ for $12 \mathrm{~h}$ showed a fine and homogeneous morphology with particle sizes of 1-3 $\mu \mathrm{m}$. With excitation at $980 \mathrm{~nm}$, the co-doped particles exhibited a strong $525 \mathrm{~nm}$ emission band and a weak 550 $\mathrm{nm}$ emission band in the green region and a weak $655 \mathrm{~nm}$ emission band in the red region. The upconversion intensity of $\mathrm{CaLa}_{2}\left(\mathrm{MoO}_{4}\right)_{4}: \mathrm{Er}^{3+} /$ $\mathrm{Yb}^{3+} \#$ particles was much higher than those of the $\mathrm{CaLa}_{2}\left(\mathrm{MoO}_{4}\right)_{4}: \mathrm{Er}^{3+}$ and $\mathrm{CaLa}_{2}\left(\mathrm{MoO}_{4}\right)_{4}: \mathrm{Er}^{3+} / \mathrm{Yb}^{3+}$ particles. The Raman spectra of $\mathrm{CaLa}_{2}\left(\mathrm{MoO}_{4}\right)_{4}: \mathrm{Er}^{3+}, \mathrm{CaLa}_{2}\left(\mathrm{MoO}_{4}\right)_{4}: \mathrm{Er}^{3+} / \mathrm{Yb}^{3+}$ and $\mathrm{CaLa}_{2}\left(\mathrm{MoO}_{4}\right)_{4}: \mathrm{Er}^{3+} / \mathrm{Yb}^{3+} \#$ particles indicated the detection of additional strong peaks at higher frequencies $\left(1026,1092\right.$ and $\left.1316 \mathrm{~cm}^{-1}\right)$ and weak peaks at lower frequencies $\left(236,288,365,420\right.$ and $\left.560 \mathrm{~cm}^{-1}\right)$.

Keywords: $\mathrm{CaLa}_{2}\left(\mathrm{MoO}_{4}\right)_{4}: \mathrm{Er}^{3+} / \mathrm{Yb}^{3+}$ particles, Microwave-assisted sol-gel, Upconversion photoluminescence.

\section{INTRODUCTION}

Recently, rare earth doped upconversion photoluminescence particles have attracted great attention because of the conversion from near infrared radiation of low energy to visible radiation of high energy. The upconversion photoluminescence particles have shown potential applications in various fields including biomedical imaging owing to their unique upconversion optical behaviors that offer improved light penetration depth, high chemical and photo stability, as well as the absence of auto-fluorescence during imaging, sharp emission bands and high resistance to photobleaching, which overcome the current limitations in traditional photoluminescence materials ${ }^{1-3}$. Double molybdates are relatively stable in the air and has stable physical and chemical properties, a low excitation threshold energy and low-cost productivity ${ }^{4-6}$. Among the rare earth ions, the $\mathrm{Er}^{3+}$ ion is suitable for converting infrared to visible light through the upconversion process due to proper electronic energy level configuration. The co-doped $\mathrm{Yb}^{3+}$ ion and $\mathrm{Er}^{3+}$ ion can remarkably enhance the upconversion efficiency from infrared to visible light due to the efficiency energy transfer from $\mathrm{Yb}^{3+}$ to $\mathrm{Er}^{3+}$. The $\mathrm{Yb}^{3+}$ ion as a sensitizer can be effectively excited by incident light source energy that is transferred to the activator, from which radiation can be emitted. The $\mathrm{Er}^{3+}$ ion activator is the luminescence center of the upconversion particles, while the sensitizer enhances the upconversion luminescence efficiency ${ }^{7-9}$.
Several processes have recently been developed to prepare the rare-earth doped double molybdates, including solid-state reactions ${ }^{10-14}$, co-precipitation ${ }^{15,16}$, sol-gel method ${ }^{4-6,17-21}$, hydrothermal method ${ }^{22,23}$, Pechni method ${ }^{24,25}$, organic gel-thermal decomposition ${ }^{26}$ and microwave-assisted hydrothermal $\operatorname{method}^{27}$. For practical application of upconversion photoluminescence in such products as lasers, three-dimensional displays, light-emitting devices and biological detectors, features such as homogeneous upconversion particle size distribution and morphology need to be well defined. Usually, the double molybdates were prepared by solid-state method that requires high temperatures, lengthy heating process and subsequent grinding, which results in the loss of emission intensity and the increase of cost. Sol-gel process has some advantages over the conventional solid-state method, including good homogeneity, low calcination temperature and a small size and narrow particle size distribution for good luminescent characteristics. However, sol-gel process has a disadvantage to take a long time period of gelation. Compared with the usual methods, microwave synthesis has the advantages of very short reaction time, small-size particles, narrow particle size distribution and high purity for preparing polycrystalline samples. Microwave heating is delivered to the material surface by radiant and/or convection heating, which is transferred to the bulk of the material via conduction ${ }^{28-32}$. Cyclic microwaveassisted sol-gel process is a cost-effective method that provides high homogeneity with easy scale-up and is emerging as a 
viable alternative approach for the synthesis of high-quality luminescent materials in short time periods.

In this study, $\mathrm{Er}^{3+}$ doped $\mathrm{CaLa}_{2}\left(\mathrm{MoO}_{4}\right)_{4}$ and $\mathrm{Er}^{3+} / \mathrm{Yb}^{3+}$ codoped $\mathrm{CaLa}_{2}\left(\mathrm{MoO}_{4}\right)_{4}$ particles were synthesized by a microwave-assisted sol-gel method, followed by heat treatment. The synthesized particles were characterized by X-ray diffraction (XRD), scanning electron microscopy (SEM) and energydispersive X-ray spectroscopy (EDS). Optical properties were examined comparatively using photoluminescence (PL) emission and Raman spectroscopy.

\section{EXPERIMENTAL}

Appropriate stoichiometric amounts of $\mathrm{Ca}\left(\mathrm{NO}_{3}\right)_{2} \cdot 4 \mathrm{H}_{2} \mathrm{O}$ (99\%, Sigma-Aldich, USA), $\mathrm{La}\left(\mathrm{NO}_{3}\right)_{3} \cdot 6 \mathrm{H}_{2} \mathrm{O}$ (99\%, SigmaAldich, USA), $\left(\mathrm{NH}_{4}\right)_{6} \mathrm{Mo}_{7} \mathrm{O}_{24} \cdot 4 \mathrm{H}_{2} \mathrm{O}$ (99\%, Alfa Aesar, USA), $\mathrm{Er}\left(\mathrm{NO}_{3}\right)_{3} \cdot 5 \mathrm{H}_{2} \mathrm{O}\left(99.9 \%\right.$, Sigma-Aldich, USA), $\mathrm{Yb}\left(\mathrm{NO}_{3}\right)_{3} \cdot 5 \mathrm{H}_{2} \mathrm{O}$ (99.9\%, Sigma-Aldich, USA), citric acid (99.5\%, Daejung Chemicals, Korea), $\mathrm{NH}_{4} \mathrm{OH}$ (A.R.), ethylene glycol (A.R.) and distilled water were used to prepare $\mathrm{CaLa}_{2}\left(\mathrm{MoO}_{4}\right)_{4}$, $\mathrm{CaLa}_{2}\left(\mathrm{MoO}_{4}\right)_{4}: \mathrm{Er}^{3+}, \mathrm{CaLa}_{2}\left(\mathrm{MoO}_{4}\right)_{4}: \mathrm{Er}^{3+} / \mathrm{Yb}^{3+}$ and $\mathrm{CaLa}_{2}\left(\mathrm{MoO}_{4}\right)_{4}$ : $\mathrm{Er}^{3+}, \mathrm{Yb}^{3+} \#$ compounds. To prepare $\mathrm{CaLa}_{2}\left(\mathrm{MoO}_{4}\right)_{4}, 0.4 \mathrm{~mol} \%$ $\mathrm{Ca}\left(\mathrm{NO}_{3}\right)_{2} \cdot 4 \mathrm{H}_{2} \mathrm{O}$ and $0.4 \mathrm{~mol} \%\left(\mathrm{NH}_{4}\right)_{6} \mathrm{Mo}_{7} \mathrm{O}_{24} \cdot 4 \mathrm{H}_{2} \mathrm{O}$ were dissolved in $20 \mathrm{~mL}$ of ethylene glycol and $80 \mathrm{~mL} 4 \mathrm{M} \mathrm{NH}_{4} \mathrm{OH}$ under vigorous stirring and heating. Subesquently, $0.8 \mathrm{~mol} \%$ $\mathrm{La}\left(\mathrm{NO}_{3}\right)_{3} \cdot 6 \mathrm{H}_{2} \mathrm{O}$ and citric acid (with molar ratio citric acid: total metal ion $=2: 1$ ) were dissolved in $100 \mathrm{~mL}$ of distilled water under vigorous stirring and heating. The solutions were mixed together under vigorous stirring and heating. At the end, the highly transparent solutions were obtained and adjusted to $\mathrm{pH} 7-8$ by addition of $8 \mathrm{M} \mathrm{NH}_{4} \mathrm{OH}$. In the second way, to prepare $\mathrm{CaLa}_{2}\left(\mathrm{MoO}_{4}\right)_{4}: \mathrm{Er}^{3+}, 0.72 \mathrm{~mol} \% \mathrm{La}\left(\mathrm{NO}_{3}\right)_{3} \cdot 6 \mathrm{H}_{2} \mathrm{O}$ with $0.08 \mathrm{~mol} \% \mathrm{Er}\left(\mathrm{NO}_{3}\right)_{3} \cdot 5 \mathrm{H}_{2} \mathrm{O}$ was used for the rare earth solution. In the third way, to prepare $\mathrm{CaLa}_{2}\left(\mathrm{MoO}_{4}\right)_{4}: \mathrm{Er}^{3+}, \mathrm{Yb}^{3+}$, $0.68 \mathrm{~mol} \% \mathrm{La}\left(\mathrm{NO}_{3}\right)_{3} \cdot 6 \mathrm{H}_{2} \mathrm{O}$ with $0.04 \mathrm{~mol} \% \mathrm{Er}\left(\mathrm{NO}_{3}\right)_{3} \cdot 5 \mathrm{H}_{2} \mathrm{O}$ and $0.08 \mathrm{~mol} \% \mathrm{Yb}\left(\mathrm{NO}_{3}\right)_{3} \cdot 5 \mathrm{H}_{2} \mathrm{O}$ was used for the rare earth solution. In the fourth way, to prepare $\mathrm{CaLa}_{2}\left(\mathrm{MoO}_{4}\right)_{4}: \mathrm{Er}^{3+}$, $\mathrm{Yb}^{3+} \#, 0.6 \mathrm{~mol} \% \mathrm{La}\left(\mathrm{NO}_{3}\right)_{3} \cdot 6 \mathrm{H}_{2} \mathrm{O}$ with $0.02 \mathrm{~mol} \% \mathrm{Er}\left(\mathrm{NO}_{3}\right)_{3} \cdot 5 \mathrm{H}_{2} \mathrm{O}$ and $0.18 \mathrm{~mol} \% \mathrm{Yb}\left(\mathrm{NO}_{3}\right)_{3} \cdot 5 \mathrm{H}_{2} \mathrm{O}$ was used for the rare earth solution.

The transparent solutions were placed into a microwave oven operating at a frequency of $2.45 \mathrm{GHz}$ with a maximum out-power of $1250 \mathrm{~W}$ for $0.5 \mathrm{~h}$. The working cycle of the microwave reaction was controlled precisely between $30 \mathrm{~s}$ on and $30 \mathrm{~s}$ off for $15 \mathrm{~min}$ and followed by a further treatment of $30 \mathrm{~s}$ on and $60 \mathrm{~s}$ off for $15 \mathrm{~min}$. The ethylene glycol was evaporated slowly at its boiling point. Ethylene glycol is a polar solvent at its boiling point of $197{ }^{\circ} \mathrm{C}$, is a good candidate for the microwave process. When ethylene glycol is used as the solvent, the reactions proceed at the boiling point temperature. When microwave radiation is supplied to the ethylene glycol based solution, the components dissolved in the ethylene glycol can couple. When a large amount of microwave radiation is supplied to the ethylene glycol, the charged particles vibrate in the electric field interdependently. The samples were treated with ultrasonic radiation for $10 \mathrm{~min}$ and to produce a light yellow transparent sol. The light yellow transparent sols were dried at $120^{\circ} \mathrm{C}$ in a dry oven for $48 \mathrm{~h}$ to get black dried gels. The black dried gels were grinded and heat-treated at $900{ }^{\circ} \mathrm{C}$ for $12 \mathrm{~h}$ with $100{ }^{\circ} \mathrm{C}$ interval between $600-900{ }^{\circ} \mathrm{C}$. Finally, the white particles were obtained for $\mathrm{CaLa}_{2}\left(\mathrm{MoO}_{4}\right)_{4}$ and pink particles for $\mathrm{CaLa}_{2}\left(\mathrm{MoO}_{4}\right)_{4}: \mathrm{Er}^{3+}, \mathrm{CaLa}_{2}\left(\mathrm{MoO}_{4}\right)_{4}: \mathrm{Er}^{3+} / \mathrm{Yb}^{3+}$ and $\mathrm{CaLa}_{2}\left(\mathrm{MoO}_{4}\right)_{4}: \mathrm{Er}^{3+} / \mathrm{Yb}^{3+} \#$.

The phase composition of the synthesized particles was identified using XRD (D/MAX 2200, Rigaku, Japan). The microstructure and surface morphology of the $\mathrm{CaLa}_{2}\left(\mathrm{MoO}_{4}\right)_{4}$, $\mathrm{CaLa}_{2}\left(\mathrm{MoO}_{4}\right)_{4}: \mathrm{Er}^{3+}, \mathrm{CaLa}_{2}\left(\mathrm{MoO}_{4}\right)_{4}: \mathrm{Er}^{3+} / \mathrm{Yb}^{3+}$ and $\mathrm{CaLa}_{2}\left(\mathrm{MoO}_{4}\right)_{4}:$ $\mathrm{Er}^{3+} / \mathrm{Yb}^{3+} \#$ particles were observed using SEM/EDS (JSM5600, JEOL, Japan). The PL spectra were recorded using a spectrophotometer (Perkin Elmer LS55, UK) at room temperature. Raman spectroscopy measurements were performed using a LabRam Aramis (Horiba Jobin-Yvon, France). The $514.5 \mathrm{~nm}$ line of an Ar ion laser was used as an excitation source and the power on the samples was kept at $0.5 \mathrm{~mW}$.

\section{RESULTS AND DISCUSSION}

Fig. 1 shows the XRD patterns of the (a) JCPDS 08-0482 data of $\mathrm{SrMoO}_{4}$, the synthesized (b) $\mathrm{CaLa}_{2}\left(\mathrm{MoO}_{4}\right)_{4}$, (c) $\mathrm{CaLa}_{2}\left(\mathrm{MoO}_{4}\right)_{4}: \mathrm{Er}^{3+}$, (d) $\mathrm{CaLa}_{2}\left(\mathrm{MoO}_{4}\right)_{4}: \mathrm{Er}^{3+} / \mathrm{Yb}^{3}$ and (e) $\mathrm{CaLa}_{2}\left(\mathrm{MoO}_{4}\right)_{4}: \mathrm{Er}^{3+} / \mathrm{Yb}^{3+} \#$ particles. All of the XRD peaks could be assigned to the tetragonal-phase $\mathrm{SrMoO}_{4}$ with a scheelite-type structure of space group I4 $4_{1 / \mathrm{a}}$ with lattice parameters of $\mathrm{a}=\mathrm{b}=5.3796 \AA$ and $\mathrm{c}=11.9897 \AA 32-35$, which was in good agreement with the crystallographic data of $\mathrm{SrMoO}_{4}$ (JCPDS 08-0482). This means that the tetragonalphase $\mathrm{CaLa}_{2}\left(\mathrm{MoO}_{4}\right)_{4}, \mathrm{CaLa}_{2}\left(\mathrm{MoO}_{4}\right)_{4}: \mathrm{Er}^{3+}, \mathrm{CaLa}_{2}\left(\mathrm{MoO}_{4}\right)_{4}: \mathrm{Er}^{3+} /$ $\mathrm{Yb}^{3}$ and $\mathrm{CaLa}_{2}\left(\mathrm{MoO}_{4}\right)_{4}: \mathrm{Er}^{3+} / \mathrm{Yb}^{3+} \#$ can be prepared using the cyclic microwave-modified sol-gel method. This suggests that the cyclic microwave-assisted sol-gel method is suitable for the growth of $\mathrm{CaLa}_{2}\left(\mathrm{MoO}_{4}\right)_{4}, \mathrm{CaLa}_{2}\left(\mathrm{MoO}_{4}\right)_{4}: \mathrm{Er}^{3+}, \mathrm{CaLa}_{2}\left(\mathrm{MoO}_{4}\right)_{4}$ : $\mathrm{Er}^{3+} / \mathrm{Yb}^{3}$ and $\mathrm{CaLa}_{2}\left(\mathrm{MoO}_{4}\right)_{4}: \mathrm{Er}^{3+} / \mathrm{Yb}^{3+} \#$ crystallites and for developing the strongest intensity peaks at the (112), (204) and (312) planes, which are the major peaks ${ }^{32-35}$ of $\mathrm{SrMoO}_{4}$. Post heat-treatment plays an important role in a well-defined crystallized morphology. Post heat-treatment plays an important role in a well-defined crystallized morphology. To achieve a well-defined crystalline morphology, the

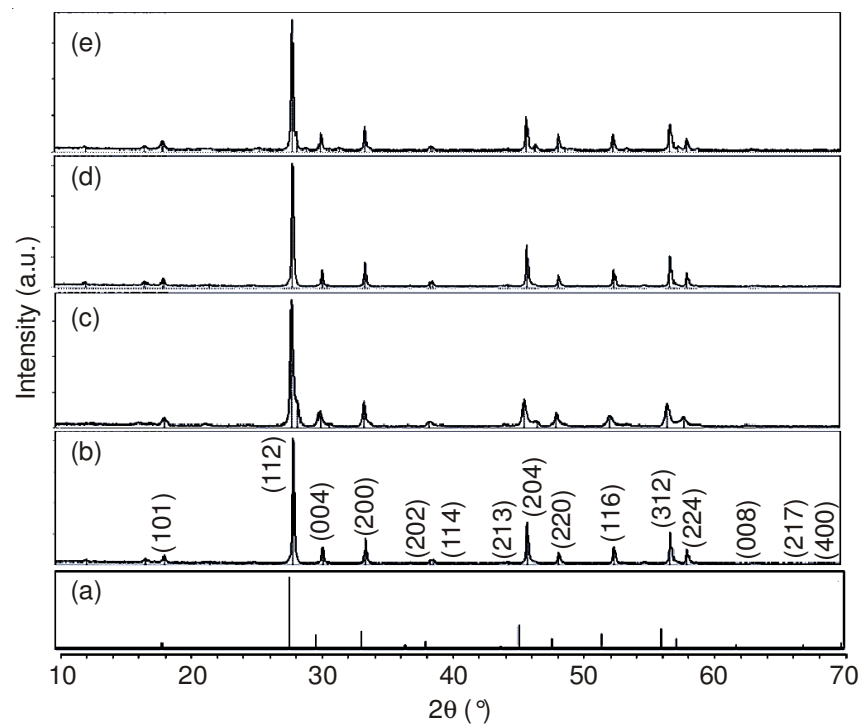

Fig. 1. X-ray diffraction patterns of the (a) JCPDS 08-0482 data of $\mathrm{SrMoO}_{4}$, the synthesized (b) $\mathrm{CaLa}_{2}\left(\mathrm{MoO}_{4}\right)_{4}$, (c) $\mathrm{CaLa}_{2}\left(\mathrm{MoO}_{4}\right)_{4}: \mathrm{Er}^{3+}$, (d) $\mathrm{CaLa}_{2}\left(\mathrm{MoO}_{4}\right)_{4}: \mathrm{Er}^{3+} / \mathrm{Yb}^{3}$ and (e) $\mathrm{CaLa}_{2}\left(\mathrm{MoO}_{4}\right)_{4}: \mathrm{Er}^{3+} / \mathrm{Yb}^{3+}$ particles 
$\mathrm{CaLa}_{2}\left(\mathrm{MoO}_{4}\right)_{4}, \mathrm{CaLa}_{2}\left(\mathrm{MoO}_{4}\right)_{4}: \mathrm{Er}^{3+}, \mathrm{CaLa}_{2}\left(\mathrm{MoO}_{4}\right)_{4}: \mathrm{Er}^{3+} / \mathrm{Yb}^{3}$ and $\mathrm{CaLa}_{2}\left(\mathrm{MoO}_{4}\right)_{4}: \mathrm{Er}^{3+} / \mathrm{Yb}^{3+} \#$ phases need to be heat treated at $900{ }^{\circ} \mathrm{C}$ for $12 \mathrm{~h}$. It is assumed that the doping amount of $\mathrm{Er}^{3+} / \mathrm{Yb}^{3+}$ has a great effect on the crystalline cell volume of the $\mathrm{CaLa}_{2}\left(\mathrm{MoO}_{4}\right)_{4}$, because of the different ionic sizes and valence states. This means that the obtained samples have a tetragonal-phase after partially replacing $\mathrm{La}^{3+}$ by $\mathrm{Er}^{3+}$ and $\mathrm{Yb}^{3+}$ ions are effectively doped into crystal lattices of the $\mathrm{CaLa}_{2}\left(\mathrm{MoO}_{4}\right)_{4}$ phase due to the similar radii ${ }^{4-6}$ of $\mathrm{La}^{3+}$ and by $\mathrm{Er}^{3+}$ and $\mathrm{Yb}^{3+}$.

Fig. 2 shows SEM images of the synthesized (a) $\mathrm{CaLa}_{2}\left(\mathrm{MoO}_{4}\right)_{4}$, (b) $\mathrm{CaLa}_{2}\left(\mathrm{MoO}_{4}\right)_{4}: \mathrm{Er}^{3+}$, (c) $\mathrm{CaLa}_{2}\left(\mathrm{MoO}_{4}\right)_{4}: \mathrm{Er}^{3+} /$ $\mathrm{Yb}^{3+}$ and (d) $\mathrm{CaLa}_{2}\left(\mathrm{MoO}_{4}\right)_{4}: \mathrm{Er}^{3+} / \mathrm{Yb}^{3+} \#$ particles. The assynthesized samples are well crystallized with a fine and homogeneous morphology and particle size of 1-3 $\mu \mathrm{m}$. The sample of (a) $\mathrm{CaLa}_{2}\left(\mathrm{MoO}_{4}\right)_{4}$ shows a very fine and homogeneous morphology with a particle size of 1-3 $\mu \mathrm{m}$. The samples of (b) $\mathrm{CaLa}_{2}\left(\mathrm{MoO}_{4}\right)_{4}: \mathrm{Er}^{3+}$, (c) $\mathrm{CaLa}_{2}\left(\mathrm{MoO}_{4}\right)_{4}: \mathrm{Er}^{3+}, \mathrm{Yb}^{3}$ and (d) $\mathrm{CaLa}_{2}\left(\mathrm{MoO}_{4}\right)_{4}: \mathrm{Er}^{3+}, \mathrm{Yb}^{3+} \#$ have some inhomogeneous particles compared to the sample of (a) $\mathrm{CaLa}_{2}\left(\mathrm{MoO}_{4}\right)_{4}$. It is noted that the doping amounts of $\mathrm{Er}^{3+}$ and $\mathrm{Yb}^{3+}$ had effects on the morphological features. Fig. 3 shows the (a) energydispersive X-ray spectroscopy patterns, (b) quantitative compositions and (c) quantitative results of the synthesized $\mathrm{CaLa}_{2}\left(\mathrm{MoO}_{4}\right)_{4}: \mathrm{Er}^{3+} / \mathrm{Yb}^{3+} \#$ particles. The EDS pattern (a) shows that the $\mathrm{CaLa}_{2}\left(\mathrm{MoO}_{4}\right)_{4}: \mathrm{Er}^{3+} / \mathrm{Yb}^{3+} \#$ particles are composed of $\mathrm{Ca}, \mathrm{La}, \mathrm{Mo}, \mathrm{O}, \mathrm{Er}$ and $\mathrm{Yb}$. The quantitative compositions (b) show precise constitutions of the synthesized $\mathrm{CaLa}_{2}\left(\mathrm{MoO}_{4}\right)_{4}$ : $\mathrm{Er}^{3+} / \mathrm{Yb}^{3+} \#$ particles. The quantitative results (c) are well presented with the weight $\%$ of $\mathrm{Ca}, \mathrm{La}, \mathrm{Mo}, \mathrm{O}, \mathrm{Er}$ and $\mathrm{Yb}$ for $\mathrm{CaLa}_{2}\left(\mathrm{MoO}_{4}\right)_{4}: \mathrm{Er}^{3+} / \mathrm{Yb}^{3+} \#$ particles. The composition of $\mathrm{Ca}$, $\mathrm{La}, \mathrm{Mo}, \mathrm{O}, \mathrm{Er}$ and $\mathrm{Yb}$ exhibits that the $\mathrm{CaLa}_{2}\left(\mathrm{MoO}_{4}\right)_{4}: \mathrm{Er}^{3+} /$ $\mathrm{Yb}^{3+}$ \# particles can be successfully synthesized using the cyclic microwave-modified sol-gel method. The cyclic microwaveassisted sol-gel process of double molybdates provides the energy to synthesize the bulk of the material uniformly, so that fine particles with controlled morphology can be fabricated in short time periods. The method is a cost-effective way to provide highly homogeneous products with easy scale-up and is a viable alternative for rapid synthesis of upconversion particles.

Fig. 4 shows the upconversion photoluminescence emission spectra of the as-prepared (a) $\mathrm{CaLa}_{2}\left(\mathrm{MoO}_{4}\right)_{4}$, (b) $\mathrm{CaLa}_{2}\left(\mathrm{MoO}_{4}\right)_{4}: \mathrm{Er}^{3+}$, (c) $\mathrm{CaLa}_{2}\left(\mathrm{MoO}_{4}\right)_{4}: \mathrm{Er}^{3+}, \mathrm{Yb}^{3+}$ and (d) $\mathrm{CaLa}_{2}\left(\mathrm{MoO}_{4}\right)_{4}: \mathrm{Er}^{3+}, \mathrm{Yb}^{3+} \#$ particles excited at $980 \mathrm{~nm}$ at room temperature. The strong $525 \mathrm{~nm}$ and the weak $550 \mathrm{~nm}$ emission bands in the green region correspond to the ${ }^{2} \mathrm{H}_{11 / 2} \rightarrow{ }^{4} \mathrm{I}_{15 / 2}$ and ${ }^{4} \mathrm{~S}_{3 / 2} \rightarrow{ }^{4} \mathrm{I}_{15 / 2}$ transitions, respectively, while the weak emission $655 \mathrm{~nm}$ band in the red region corresponds to the ${ }^{4} \mathrm{~F}_{9 / 2} \rightarrow{ }^{4} \mathrm{I}_{15 / 2}$ transition. The upconversion intensities of (a) $\mathrm{CaLa}_{2}\left(\mathrm{MoO}_{4}\right)_{4}$ and (b) $\mathrm{CaLa}_{2}\left(\mathrm{MoO}_{4}\right)_{4}: \mathrm{Er}^{3+}$ have not appeared. The upconversion intensity of (d) $\mathrm{CaLa}_{2}\left(\mathrm{MoO}_{4}\right)_{4}: \mathrm{Er}^{3+} / \mathrm{Yb}^{3+} \#$ is much higher than that of (c) $\mathrm{CaLa}_{2}\left(\mathrm{MoO}_{4}\right)_{4}: \mathrm{Er}^{3+} / \mathrm{Yb}^{3+}$ particles. Similar results are also observed from $\mathrm{Er}^{3+} / \mathrm{Yb}^{3+}$ co-doped in other host matrices, which are assigned in the upconversion emission spectra that the green emission intensity $\left({ }^{2} \mathrm{H}_{11 / 2} \rightarrow\right.$ ${ }^{4} \mathrm{I}_{15 / 2}$ and ${ }^{4} \mathrm{~S}_{3 / 2} \rightarrow{ }^{4} \mathrm{I}_{15 / 2}$ transitions) and the red emission intensity $\left({ }^{4} \mathrm{~F}_{9 / 2} \rightarrow{ }^{4} \mathrm{I}_{15 / 2} \text { transition }\right)^{7,10,23,25,30-32,36}$. The doping amounts of
$\mathrm{Er}^{3+} / \mathrm{Yb}^{3+}$ had a great effect on both the morphological features

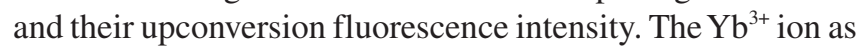
a sensitizer can be effectively excited by the energy of the incident light source, which transfers this energy to the activator, where radiation can be emitted. The $\mathrm{Er}^{3+}$ ion as an activator is the luminescence center in upconversion particles and the sensitizer enhances the upconversion luminescence efficiency.
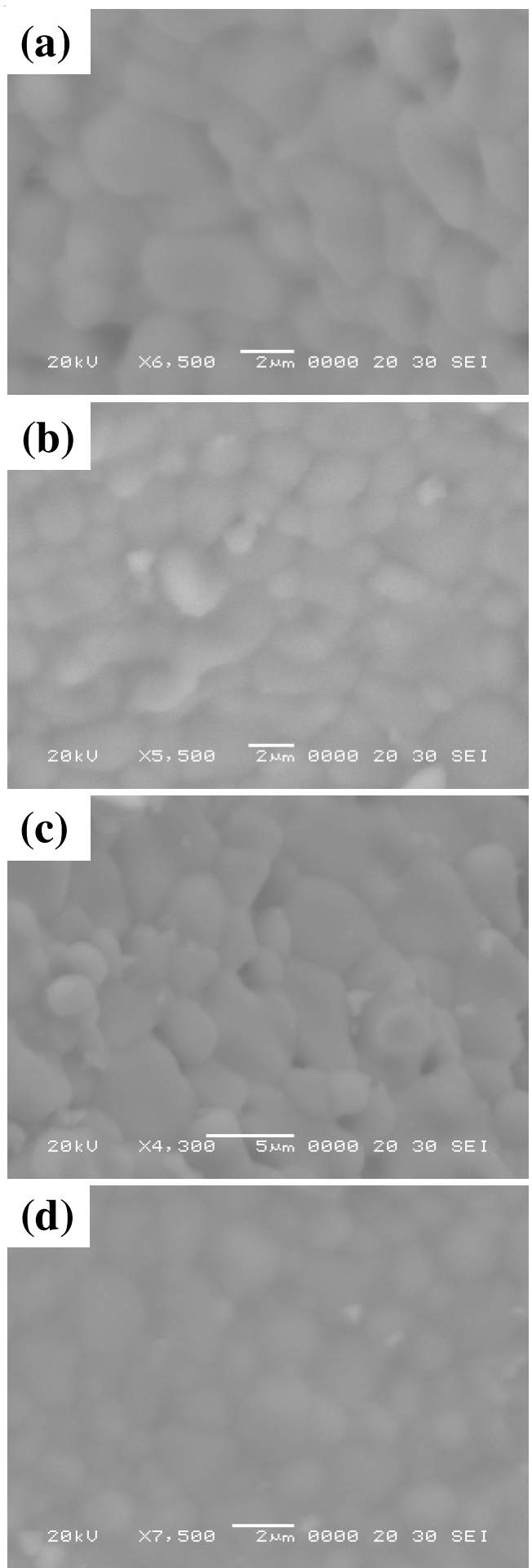

Fig. 2. Scanning electron microscopy images of the synthesized (a) $\mathrm{CaLa}_{2}\left(\mathrm{MoO}_{4}\right)_{4}$, (b) $\mathrm{CaLa}_{2}\left(\mathrm{MoO}_{4}\right)_{4}: \mathrm{Er}^{3+}$, (c) $\mathrm{CaLa}_{2}\left(\mathrm{MoO}_{4}\right)_{4}: \mathrm{Er}^{3+} / \mathrm{Yb}^{3+}$ and (d) $\mathrm{CaLa}_{2}\left(\mathrm{MoO}_{4}\right)_{4}: \mathrm{Er}^{3+} / \mathrm{Yb}^{3+} \#$ particles 
(a)

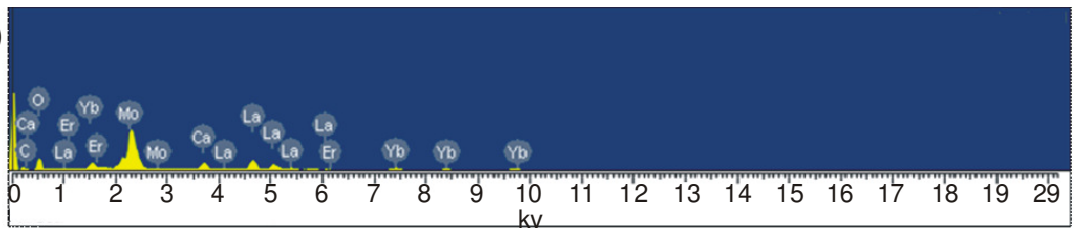

(b)

\begin{tabular}{l|lllllllll}
\hline Spectrum & In stats & $\mathrm{C}$ & $\mathrm{O}$ & $\mathrm{Ca}$ & $\mathrm{Mo}$ & $\mathrm{La}$ & $\mathrm{Er}$ & $\mathrm{Yb}$ & Total \\
Spectrum 1 & Yes & 16.37 & 32.20 & 2.69 & 28.00 & 13.63 & 0.80 & 6.32 & 100.00 \\
Spectrum 2 & Yes & 15.29 & 32.39 & 2.64 & 28.77 & 13.99 & 0.67 & 6.25 & 100.00 \\
Spectrum 3 & Yes & 17.49 & 32.43 & 2.53 & 27.01 & 13.30 & 0.68 & 6.57 & 100.00 \\
Spectrum 4 & Yes & 15.88 & 33.88 & 2.62 & 27.96 & 13.33 & 0.59 & 6.54 & 100.00 \\
& & & & & & & & & \\
& & 16.25 & 32.53 & 2.62 & 27.94 & 13.56 & 0.68 & 6.42 & 100.00 \\
Mean & & 0.93 & 0.38 & 0.07 & 0.72 & 0.32 & 0.08 & 0.16 & \\
Std. deviation & & 17.49 & 33.08 & 2.69 & 28.77 & 13.99 & 0.80 & 6.57 & \\
Max. & & 15.29 & 32.20 & 2.53 & 27.01 & 13.30 & 0.59 & 6.25 & \\
Min. & & & & & & & &
\end{tabular}

(C)

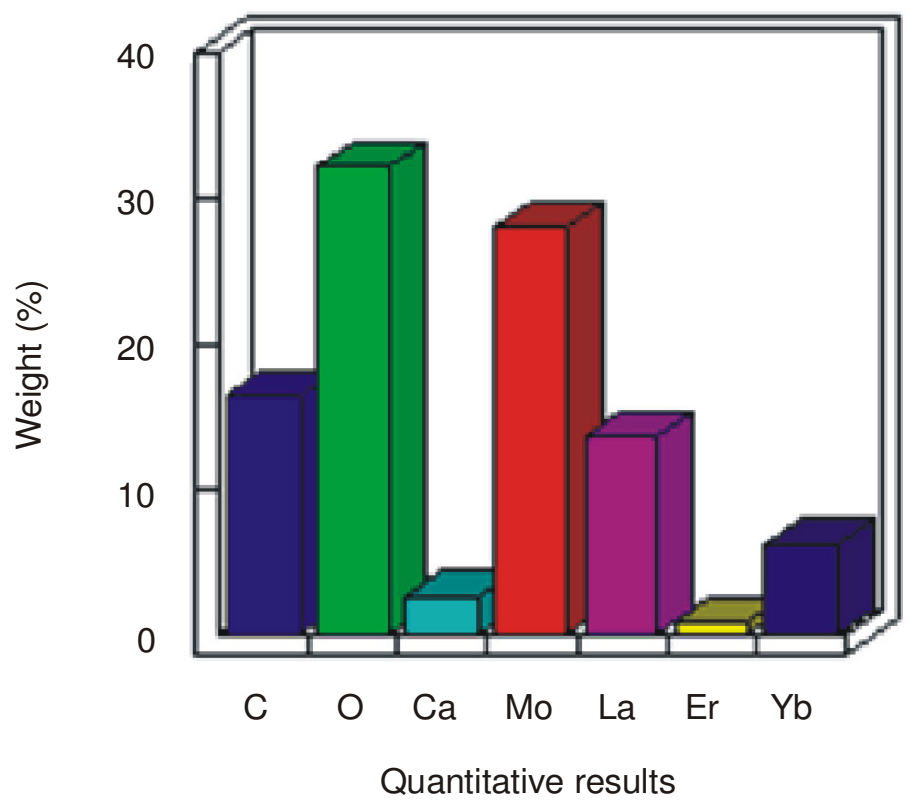

Fig. 3. Energy-dispersive X-ray spectroscopy patterns (a), quantitative compositions (b) and quantitative results (c) of the synthesized $\mathrm{CaLa}_{2}\left(\mathrm{MoO}_{4}\right)_{4}: \mathrm{Er}^{3+} /$ $\mathrm{Yb}^{3+} \#$ particles

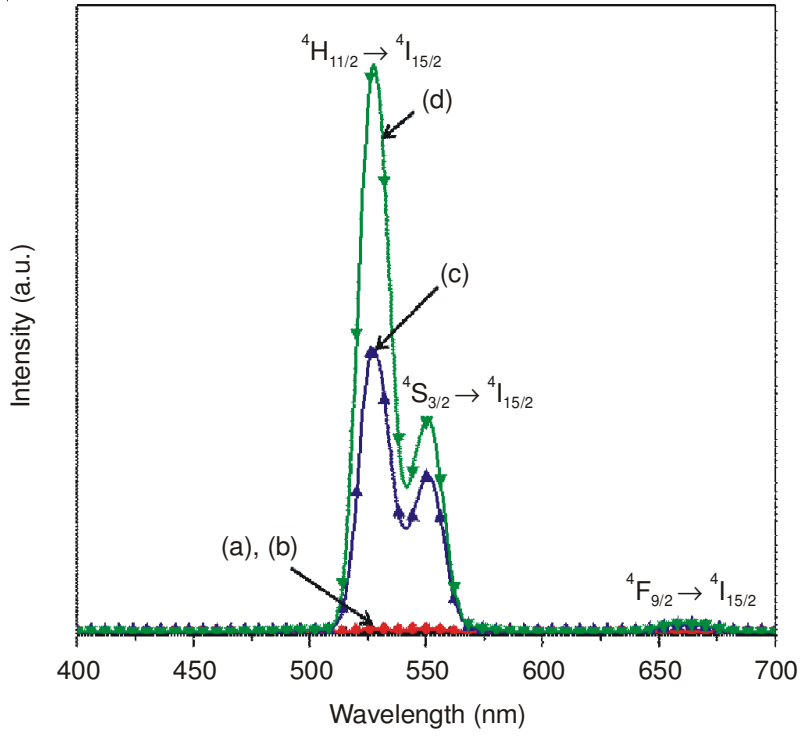

Fig. 4. Upconversion photoluminescence emission spectra of (a) $\mathrm{CaLa}_{2}$ $\left(\mathrm{MoO}_{4}\right)_{4}$, (b) $\mathrm{CaLa}_{2}\left(\mathrm{MoO}_{4}\right)_{4}: \mathrm{Er}^{3+}$, (c) $\mathrm{CaLa}_{2}\left(\mathrm{MoO}_{4}\right)_{4}: \mathrm{Er}^{3+} / \mathrm{Yb}^{3+}$ and (d) $\mathrm{CaLa}_{2}\left(\mathrm{MoO}_{4}\right)_{4}: \mathrm{Er}^{3+} / \mathrm{Yb}^{3+} \#$ particles excited at $980 \mathrm{~nm}$ at room temperature
The upconversion process is a proven successful method for generating visible light from near infrared (NIR) radiation. upconversion is a nonlinear optical process in which excitation of the lower electronic levels with low-energy radiation (NIR light) results in higher energy emission (visible or ultraviolet light) at higher electronic levels; thus it is ascribed as an antiStockes mechanism.This process requires the absorption of two or more photons to produce sufficient energy for upconversion emission. Fig. 5 shows the schematic energy level diagrams of $\mathrm{Er}^{3+}$ ions (activator) and $\mathrm{Yb}^{3+}$ ions (sensitizer) in the as-prepared $\mathrm{CaLa}_{2}\left(\mathrm{MoO}_{4}\right)_{4}: \mathrm{Er}^{3+} / \mathrm{Yb}^{3+}$ samples and the upconversion mechanisms accounting for the green and red emissions at $980 \mathrm{~nm}$ laser excitation ${ }^{32}$. In the complex $\mathrm{Er}^{3+} /$ $\mathrm{Yb}^{3+}$ co-doped $\mathrm{CaLa}_{2}\left(\mathrm{MoO}_{4}\right)_{4}$ system, $\mathrm{Er}^{3+}$ and $\mathrm{Yb}^{3+}$ ions are initially excited from the ground states to the excited states by the ground state absorption (GSA) processes $\left(\mathrm{Er}^{3+}:{ }^{4} \mathrm{I}_{15 / 2} \rightarrow{ }^{4} \mathrm{I}_{11 / 2}\right.$, $\left.\mathrm{Yb}^{3+}:{ }^{2} \mathrm{~F}_{7 / 2} \rightarrow{ }^{2} \mathrm{~F}_{5 / 2}\right)$ or ET process of ${ }^{2} \mathrm{~F}_{5 / 2}\left(\mathrm{Yb}^{3+}\right)+{ }^{4} \mathrm{I}_{15 / 2}\left(\mathrm{Er}^{3+}\right) \rightarrow$ ${ }^{4} \mathrm{~F}_{7 / 2}\left(\mathrm{Yb}^{3+}\right)+{ }^{4} \mathrm{I}_{11 / 2}\left(\mathrm{Er}^{3+}\right)$ dependent on the population of the ${ }^{4} \mathrm{I}_{11 / 2}$ level in $\mathrm{Er}^{3+}$. It is considered that these three processes are able to populate the ${ }^{4} \mathrm{~F}_{7 / 2}$ level from the ${ }^{4} \mathrm{I}_{11 / 2}$ level in the $\mathrm{Er}^{3+}$ level and then the ${ }^{4} \mathrm{~F}_{7 / 2}$ level relaxes rapidly and non-radiatively 


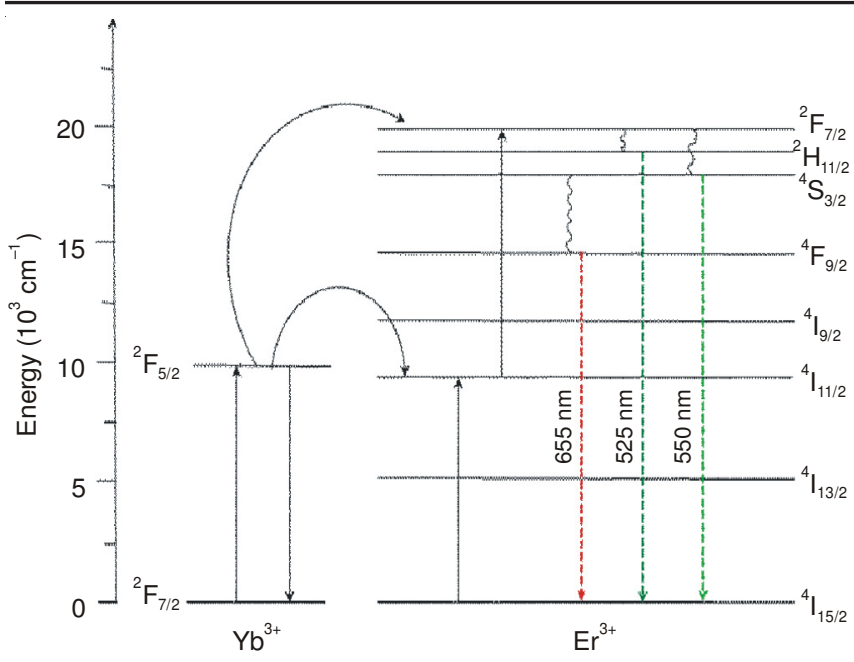

Fig. 5. Schematic energy level diagrams of $\mathrm{Er}^{3+}$ ions (activator) and $\mathrm{Yb}^{3+}$ ions (sensitizer) in the as-prepared $\mathrm{CaLa}_{2}\left(\mathrm{MoO}_{4}\right)_{4}: \mathrm{Er}^{3+} / \mathrm{Yb}^{3+}$ system and the upconversion mechanisms accounting for the green and red emissions under $980 \mathrm{~nm}$ laser excitation ${ }^{30}$

to the next lower ${ }^{2} \mathrm{H}_{11 / 2}$ and ${ }^{4} \mathrm{~S}_{3 / 2}$ in $\mathrm{Er}^{3+}$ because of short lifetime of the ${ }^{4} \mathrm{~F}_{7 / 2}$ level. Then, the radiative transitions of ${ }^{2} \mathrm{H}_{11 / 2} \rightarrow$ ${ }^{4} \mathrm{I}_{15 / 2}$ and ${ }^{4} \mathrm{~S}_{3 / 2} \rightarrow{ }^{4} \mathrm{I}_{15 / 2}$ processes can produce green emissions at 525 and $550 \mathrm{~nm}^{37}$. For the red emission, the ${ }^{4} \mathrm{~F}_{9 / 2}$ level is populated by non-radiative relaxation from the ${ }^{4} \mathrm{~S}_{3 / 2}$ to the ${ }^{4} \mathrm{~F}_{9 / 2}$ level and cross relaxation (CR) via the ${ }^{4} \mathrm{~F}_{7 / 2}+{ }^{4} \mathrm{I}_{11 / 2} \rightarrow{ }^{4} \mathrm{~F}_{9 / 2}+$ ${ }^{4} \mathrm{~F}_{9 / 2}$ transition ${ }^{38}$ in $\mathrm{Er}^{3+}$. Finally, ${ }^{4} \mathrm{~F}_{9 / 2}$ level relaxes radiatively to the ground state at ${ }^{4} \mathrm{I}_{15 / 2}$ level and releases red emission at $655 \mathrm{~nm}$. The strong $525 \mathrm{~nm}$ and the weak $550 \mathrm{~nm}$ emission bands in the green region as shown in Fig. 4 are assigned to the ${ }^{2} \mathrm{H}_{11 / 2} \rightarrow{ }^{4} \mathrm{I}_{15 / 2}$ and ${ }^{4} \mathrm{~S}_{3 / 2} \rightarrow{ }^{4} \mathrm{I}_{15 / 2}$ transitions of $\mathrm{Er}^{3+}$ ions, respectively, while the weak $655 \mathrm{~nm}$ emission band in the red region is assigned to ${ }^{4} \mathrm{~F}^{9 / 2} \rightarrow{ }^{4} \mathrm{I}_{15 / 2}$ transition. The much higher intensity of the ${ }^{2} \mathrm{H}_{11 / 2} \rightarrow{ }^{4} \mathrm{I}_{15 / 2}$ transition in comparison with that ${ }^{4} \mathrm{~S}_{3 / 2} \rightarrow{ }^{4} \mathrm{I}_{15 / 2}$ transition may be induced with the concentration quenching effect by the energy transfer between nearest $\mathrm{Er}^{3+}$ and $\mathrm{Yb}^{3+}$ ions and the interactions between doping ions in $\mathrm{CaLa}_{2}\left(\mathrm{MoO}_{4}\right)_{4}$ host matrix ${ }^{7,32,37,38}$. It means that the green band ${ }^{2} \mathrm{H}_{11 / 2} \rightarrow{ }^{4} \mathrm{I}_{15 / 2}$ transitions are assumed to be more easily quenched than that of the ${ }^{4} \mathrm{~S}_{3 / 2} \rightarrow{ }^{4} \mathrm{I}_{15 / 2}$ transition by the non-radiative relaxation in the case of $\mathrm{CaLa}_{2}\left(\mathrm{MoO}_{4}\right)_{4}$ host matrix.

Fig. 6 shows the Raman spectra of the synthesized (a) $\mathrm{CaLa}_{2}\left(\mathrm{MoO}_{4}\right)_{4}(\mathrm{CLM})$, (b) $\mathrm{CaLa}_{2}\left(\mathrm{MoO}_{4}\right)_{4}: \mathrm{Er}^{3+}$ (CLM:Er), (c) $\mathrm{CaLa}_{2}\left(\mathrm{MoO}_{4}\right)_{4}: \mathrm{Er}^{3+} / \mathrm{Yb}^{3+}(\mathrm{CLM}: \mathrm{ErYb})$ and (d) $\mathrm{CaLa}_{2}\left(\mathrm{MoO}_{4}\right)_{4}$ : $\mathrm{Er}^{3+} / \mathrm{Yb}^{3+} \#$ (CLM:ErYb\#) particles excited by the $514.5 \mathrm{~nm}$ line of an Ar ion laser at $0.5 \mathrm{~mW}$ on the samples. The internal modes for the (a) $\mathrm{CaLa}_{2}\left(\mathrm{MoO}_{4}\right)_{4}(\mathrm{CLM})$ particles were detected as $v_{1}\left(A_{g}\right), v_{3}\left(B_{g}\right), v_{3}\left(E_{g}\right), v_{4}\left(E_{g}\right), v_{4}\left(B_{g}\right)$ and $v_{2}\left(B_{g}\right)$ vibrations at $318,357,380,766,838$ and $906 \mathrm{~cm}^{-1}$, respectively. The wellresolved sharp peaks for the $\mathrm{CaLa}_{2}\left(\mathrm{MoO}_{4}\right)_{4}$ particles indicate the high crystallization of the synthesized particles. The internal vibration mode frequencies are dependent on the lattice parameters and the degree of the partially covalent bond between the cation and molecular ionic group $\left[\mathrm{MoO}_{4}\right]^{2-}$. The Raman spectra of the (b) $\mathrm{CaLa}_{2}\left(\mathrm{MoO}_{4}\right)_{4}: \mathrm{Er}^{3+}$ (CLM:Er), (c) $\mathrm{CaLa}_{2}\left(\mathrm{MoO}_{4}\right)_{4}: \mathrm{Er}^{3+} / \mathrm{Yb}^{3+}(\mathrm{CLM}: \mathrm{ErYb})$ and (d) $\mathrm{CaLa}_{2}\left(\mathrm{MoO}_{4}\right)_{4}$ : $\mathrm{Er}^{3+} / \mathrm{Yb}^{3+} \#$ (CLM:ErYb\#) particles indicate additional strong

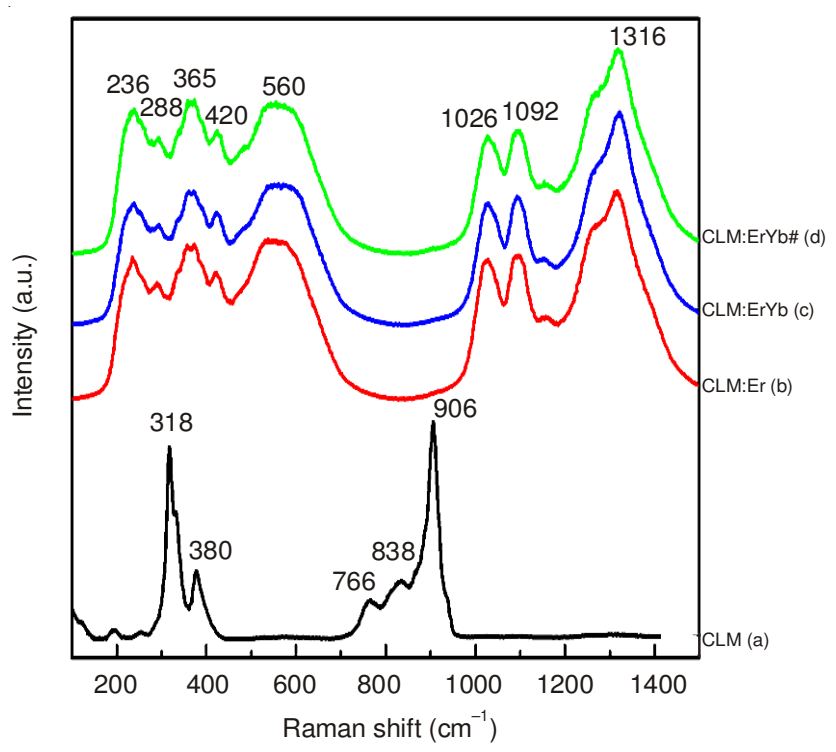

Fig. 6. Raman spectra of the synthesized (a) $\mathrm{CaLa}_{2}\left(\mathrm{MoO}_{4}\right)_{4}(\mathrm{CLM})$, (b) $\mathrm{CaLa}_{2}\left(\mathrm{MoO}_{4}\right)_{4}: \mathrm{Er}^{3+}(\mathrm{CLM}: \mathrm{Er}),(\mathrm{c}) \mathrm{CaLa}_{2}\left(\mathrm{MoO}_{4}\right)_{4}: \mathrm{Er}^{3+} / \mathrm{Yb}^{3+}(\mathrm{CLM}$ : $\mathrm{ErYb})$ and (d) $\mathrm{CaLa}_{2}\left(\mathrm{MoO}_{4}\right)_{4}: \mathrm{Er}^{3+} / \mathrm{Yb}^{3+} \#$ (CLM:ErYb\#) particles excited by the $514.5 \mathrm{~nm}$ line of an Ar ion laser at $0.5 \mathrm{~mW}$ on the samples

peaks at higher frequencies $\left(1026,1092\right.$ and $\left.1316 \mathrm{~cm}^{-1}\right)$ and weak peaks at lower frequencies $(236,288,365,420$ and 560 $\left.\mathrm{cm}^{-1}\right)$. The Raman spectra of $\mathrm{CaLa}_{2}\left(\mathrm{MoO}_{4}\right)_{4}: \mathrm{Er}^{3+}, \mathrm{CaLa}_{2}$ $\left(\mathrm{MoO}_{4}\right)_{4}: \mathrm{Er}^{3+} / \mathrm{Yb}^{3+}$ and $\mathrm{CaLa}_{2}\left(\mathrm{MoO}_{4}\right)_{4}: \mathrm{Er}^{3+} / \mathrm{Yb}^{3+} \#$ particles proved that the doping ions can influence the structure of the host materials. The combination of a heavy metal cation and the large inter-ionic distance for $\mathrm{Er}^{3+}$ and $\mathrm{Yb}^{3+}$ substitutions in $\mathrm{La}^{3+}$ sites in the lattice result in low probability of upconversion and the phonon-splitting relaxation in $\mathrm{CaLa}_{2}\left(\mathrm{MoO}_{4}\right)_{4}$ crystals. Raman spectra of $\mathrm{Er}^{3+}$ doped and $\mathrm{Er}^{3+} / \mathrm{Yb}^{3+}$ co-doped $\mathrm{CaLa}_{2}\left(\mathrm{MoO}_{4}\right)_{4}$ recorded in the present study are assigned to the previously reported results for $\mathrm{Er}^{3+} / \mathrm{Yb}^{3+}$ co-doped $\mathrm{MMoO}_{4}$ $(\mathrm{M}=\mathrm{Ba}, \mathrm{Sr}, \mathrm{Ca})$ systems $^{30-32}$. It could consider that the very strong and strange effect in the Ln-doped crystalline samples may be generated by the disorder of the $\left[\mathrm{MoO}_{4}\right]^{2-}$ groups with the incorporation of the Ln element into the crystal lattice or by a new phase formation.

\section{Conclusion}

$\mathrm{Er}^{3+} / \mathrm{Yb}^{3+}$ co-doped $\mathrm{CaLa}_{2}\left(\mathrm{MoO}_{4}\right)_{4}: \mathrm{Er}^{3+} / \mathrm{Yb}^{3+}\left(\mathrm{CaLa}_{2}\right.$ $\left.\left(\mathrm{MoO}_{4}\right)_{4}: \mathrm{Er}^{3+} / \mathrm{Yb}^{3+}\right)$ upconversion particles were successfully synthesized by a cyclic microwave-assisted sol-gel method. Well-crystallized $\mathrm{CaLa}_{2}\left(\mathrm{MoO}_{4}\right)_{4}, \mathrm{CaLa}_{2}\left(\mathrm{MoO}_{4}\right)_{4}: \mathrm{Er}^{3+}$, $\mathrm{CaLa}_{2}\left(\mathrm{MoO}_{4}\right)_{4}: \mathrm{Er}^{3+} / \mathrm{Yb}^{3+}$ and $\mathrm{CaLa}_{2}\left(\mathrm{MoO}_{4}\right)_{4}: \mathrm{Er}^{3+} / \mathrm{Yb}^{3+} \#$ particles formed after heat-treatment at $900{ }^{\circ} \mathrm{C}$ for $12 \mathrm{~h}$ showed a fine and homogeneous morphology with particle sizes of 1$3 \mu \mathrm{m}$. With excitation at $980 \mathrm{~nm}, \mathrm{CaLa}_{2}\left(\mathrm{MoO}_{4}\right)_{4}: \mathrm{Er}^{3+} / \mathrm{Yb}^{3+} \#$ particles exhibited a strong $525 \mathrm{~nm}$ and a weak $550 \mathrm{~nm}$ emission bands in the green region, which were assigned to the ${ }^{2} \mathrm{H}_{11 / 2} \rightarrow{ }^{4} \mathrm{I}_{15 / 2}$ and ${ }^{4} \mathrm{~S}_{3 / 2} \rightarrow{ }^{4} \mathrm{I}_{15 / 2}$ transitions, respectively, while a weak $655 \mathrm{~nm}$ emission band in the red region was assigned to the ${ }^{4} \mathrm{~F}_{9 / 2} \rightarrow{ }^{4} \mathrm{I}_{15 / 2}$ transition. The upconversion intensity of $\mathrm{CaLa}_{2}\left(\mathrm{MoO}_{4}\right)_{4}: \mathrm{Er}^{3+} / \mathrm{Yb}^{3+} \#$ particles was much higher than those of the $\mathrm{CaLa}_{2}\left(\mathrm{MoO}_{4}\right)_{4}: \mathrm{Er}^{3+}$ and $\mathrm{CaLa}_{2}\left(\mathrm{MoO}_{4}\right)_{4}: \mathrm{Er}^{3+} / \mathrm{Yb}^{3+}$ particles. The Raman spectra of $\mathrm{CaLa}_{2}\left(\mathrm{MoO}_{4}\right)_{4}: \mathrm{Er}^{3+}$, 
$\mathrm{CaLa}_{2}\left(\mathrm{MoO}_{4}\right)_{4}: \mathrm{Er}^{3+} / \mathrm{Yb}^{3+}$ and $\mathrm{CaLa}_{2}\left(\mathrm{MoO}_{4}\right)_{4}: \mathrm{Er}^{3+} / \mathrm{Yb}^{3+} \#$ particles indicated the detection of additional strong peaks at higher frequencies $\left(1026,1092\right.$ and $\left.1316 \mathrm{~cm}^{-1}\right)$ and weak peaks at lower frequencies $\left(236,288,365,420\right.$ and $\left.560 \mathrm{~cm}^{-1}\right)$.

\section{ACKNOWLEDGEMENTS}

This study was supported by the Basic Science Research Program through the National Research Foundation of Korea (NRF) funded by the Ministry of Education, Science and Technology (2014-046024).

\section{REFERENCES}

1. M. Wang, G. Abbineni, A. Clevenger, C. Mao and S. Xu, Nanomedicine, 7, 710 (2011).

2. A. Shalav, B.S. Richards and M.A. Green, Sol. Energy Mater. Sol. Cells, 91, 829 (2007)

3. C. Zhang, L. Sun, Y. Zhang and C. Yan, J. Rare Earths, 28, 807 (2010).

4. J. Liao, D. Zhou, B. Yang, R. Liu, Q. Zhang and Q. Zhou, J. Lumin., 134, 533 (2013).

5. J. Sun, Y. Lan, Z. Xia and H. Du, Opt. Mater., 33, 576 (2011).

6. C. Guo, H.K. Yang and J.H. Jeong, J. Lumin., 130, 1390 (2010).

7. J. Sun, J. Xian and H. Du, J. Phys. Chem. Solids, 72, 207 (2011)

8. J. Sun, J. Xian, Z. Xia and H. Du, J. Rare Earths, 28, 219 (2010).

9. V.K. Komarala, Y. Wang and M. Xiao, Chem. Phys. Lett., 490, 189 (2010).

10. H. Du, Y. Lan, Z. Xia and J. Sun, Mater. Res. Bull., 44, 1660 (2009).

11. L.X. Pang, H. Liu, D. Zhou, G.B. Sun, W.B. Qin and W.G. Liu, Mater. Lett., 72, 128 (2012).

12. M. Haque and D.K. Kim, Mater. Lett., 63, 793 (2009).

13. H. Du, Y. Lan, Z. Xia and J. Sun, Mater. Res. Bull., 44, 1660 (2009).

14. L. Qin, Y. Huang, T. Tsuboi and H.J. Seo, Mater. Res. Bull., 47, 4498 (2012).

15. Y. Yang, E. Liu, L. Li, Z. Huang, H. Shen and X.- Xiang, J. Alloys Comp., 505, 555 (2010).

16. Y. Tian, B. Chen, B. Tian, R. Hua, J. Sun, L. Cheng, H. Zhong, X. Li, J. Zhang, Y. Zheng, T. Yu, L. Huang and Q. Meng, J. Alloys Comp., 509, 6096 (2011).
17. T. Li, C. Guo, Y. Wu, L. Li and J.H. Jeong, J. Alloys Comp., 540, 107 (2012).

18. C. Guo, T. Chen, L. Luan, W. Zhang and D. Huang, J. Phys. Chem. Solids, 69, 1905 (2008).

19. J. Liao, H. Huang, H. You, X. Qiu, Y. Li, B. Qiu and H.R. Wen, Mater. Res. Bull., 45, 1145 (2010).

20. C. Guo, W. Zhang, L. Luan, T. Chen, H. Cheng and D. Huang, Sens. Actuators B, 133, 33 (2008).

21. J. Liao, H. You, D. Zhou, H.R. Wen and R. Hong, Opt. Mater., 34, 1468 (2012).

22. Y. Huang, L. Zhou, L. Yang and Z. Tang, Opt. Mater., 33, 777 (2011).

23. Y. Tian, B. Chen, B. Tian, J. Sun, X. Li, J. Zhang, L. Cheng, H. Zhong, H. Zhong, Q. Meng and R. Hua, Physica B, 407, 2556 (2012).

24. Z. Wang, H. Liang, L. Zhou, J. Wang, M. Gong and Q. Su, J. Lumin., 128, 147 (2008).

25. Q. Chen, L. Qin, Z. Feng, R. Ge, X. Zhao and H. Xu, J. Rare Earths, 29, 843 (2011).

26. X. Shen, L. Li, F. He, X. Meng and F. Song, Mater. Chem. Phys., 132, 471 (2012)

27. J. Zhang, X. Wang, X. Zhang, X. Zhao, X. Liu and L. Peng, Inorg. Chem. Commun., 14, 1723 (2011).

28. C.S. Lim, Mater. Chem. Phys., 131, 714 (2012).

29. C.S. Lim, J. Lumin., 132, 1774 (2012).

30. C.S. Lim, Mater. Res. Bull., 47, 4220 (2012).

31. C.S. Lim, Mater. Chem. Phys., 140, 154 (2013).

32. C.S. Lim, Mater. Res. Bull., 48, 3805 (2013).

33. J.C. Sczancoski, L.S. Cavalcante, M.R. Joya, J.A. Varela, P.S. Pizani and E. Longo, Chem. Eng. J., 140, 632 (2008).

34. T. Thongtem, S. Kungwankunakorn, B. Kuntalue, A. Phuruangrat and S. Thongtem, J. Alloy. Comp., 506, 475 (2010).

35. T. Thongtem, A. Phuruangrat and S. Thongtem, J. Nanopart. Res., 12, 2287 (2010).

36. W. Lu, L. Cheng, J. Sun, H. Zhong, X. Li, Y. Tian, J. Wan, Y. Zheng, L. Huang, T. Yu, H. Yu and B. Chen, Physica B, 405, 3284 (2010).

37. Sun, X. Chen, Z. Liu, F. Wang, Z. Jiang and C. Wang, J. Alloys Comp., 509, 5336 (2011).

38. J. Sun, J. Xian, X. Zhang and H. Du, J. Rare Earths, 29, 32 (2011). 